ROBERT J. GORDON

Northwestern University

\title{
Back to the Future: European Unemployment Today Viewed from America in 1939
}

ManY ECONOMISTS would agree that the two greatest macroeconomic puzzles of the twentieth century are the persistence of unemployment in the United States in the 1930s and in Europe in the 1980s. High unemployment in 1939 America was cured by a sharp expansion in aggregate demand, with a notable absence of supply bottlenecks. ${ }^{1}$ Although there are significant differences in the situations faced by America in 1939 and Europe today, the similarities are striking enough to warrant asking whether European unemployment could also melt away in response to an expansion in aggregate demand.

With inflation in Europe no longer decelerating, many analysts believe that Europe must today be operating at or close to its nonaccelerating inflation rate of unemployment, and that today's NAIRU is much higher than it was in the 1960s and early 1970s. Two different interpretations of the high NAIRU have been offered, each with quite different policy implications. Perhaps the dominant view, which I call "structuralist," explains high unemployment by supply constraints, including high real

I am grateful to members of the Brookings Panel for helpful suggestions, to the National Science Foundation for financial support, and to Daniel Shiman for indispensable research assistance. A complete data appendix is available from the author upon request. Gabriel Sensenbrenner helped to pull together data from diverse sources, and Charles Schultze generously provided his update of the European Commission data on capital stocks and other variables.

1. Throughout the paper, I treat only the peacetime expansion extending through December 1941, during which prices were free to adjust. I make a sharp distinction with the portion of the expansion that took place after war was declared, because price controls were imposed in early 1942. 
wages, government intervention in the free operation of labor markets, and other structural maladjustments, most notably inadequate capacity available to equip presently unemployed workers. According to this view, unemployment cannot be reduced until the supply-side constraints are directly addressed by supply-oriented changes in government policies. The more optimistic "hysteresis" view is that the NAIRU automatically follows in the path of the actual unemployment rate. Thus, the NAIRU in Europe is high because actual unemployment is high, and the best way to make the NAIRU decline is to pursue expansionary demand policies.

The analogy with 1939 America offers some insights into the validity of the two competing views of the current European situation. During 1939 , more than any other year in the dismal Depression decade, the American economy exhibited every evidence of slipping into a lowemployment equilibrium trap. Prices were on a plateau, with no tendency to decline, despite high unemployment. In every other year during the decade, output was either falling rapidly or rising rapidly. As in Europe today, numerous supply-side constraints, including high real wages, union militancy, and a declining capital stock, afflicted the economy. That these supply barriers melted in the face of demand expansion in 1939-41 is evidence against much of the structuralist interpretation of contemporary European problems.

Again, as in Europe today, the interwar U. S. Phillips curve relationship showed signs of hysteresis; that is, inflation depended not on the level of detrended output but on its rate of change. A low level of output did not exert continuing downward pressure on the inflation rate. ${ }^{2}$ But

2. I have previously pointed out the disappearance in the United States between 1929 and 1941, and in the United Kingdom between 1922 and 1938, of the Phillips curve "level effect" in favor of an effect working exclusively through the rate of growth of unemployment or output. This phenomenon is documented in Robert J. Gordon and James S. Wilcox, "Monetarist Interpretations of the Great Depression: An Evaluation and Critique," in Karl Brunner, ed., The Great Depression Revisited (Martinus Nijhoff, 1981), pp. 49-107; and Robert J. Gordon, "A Century of Evidence on Wage and Price Stickiness in the United States, the United Kingdom and Japan," in James Tobin, ed., Macroeconomics, Prices, and Quantities: Essays in Memory of Arthur M. Okun (Brookings, 1983), pp. 85-121. Similarities between Europe today and the United States in the late 1930s discussed subsequently in this paper are examined in Olivier J. Blanchard and Lawrence H. Summers, "Hysteresis and the European Unemployment Problem," in Stanley Fischer, ed., NBER Macroeconomics Annual, 1986 (MIT Press, 1986), pp. 65-71. A discussion of high real wages and reduced profit margins in the 1928-32 contraction, and their reversal in the 
the inflation-output relationship in 1939 reveals a critical difference as well. Inflation was not nearly as persistent in interwar America as in postwar Europe, and as a result the United States in 1939 faced a more favorable inflation-output trade-off than does Europe today, in the sense that higher inflation coming from a rapid expansion would eventually die out.

\section{A Few Essential Facts}

Figure 1 charts U. S. and European unemployment since 1961. Here, as in subsequent tables, "Europe" refers to the six original members of the European Community, plus the United Kingdom, Austria, Norway, Sweden, and Switzerland. By late 1987 unemployment in the United States had fallen to the level reached in 1963, while European unemployment in late 1987 exceeded that in 1963 by a factor of five. The upsurge in European unemployment took place in two phases, first in 1974-76 at the time of the first oil shock, and then in 1980-83 at the time of the second oil shock and the worldwide contraction in aggregate demand. There was no further increase in European unemployment after 1984, but no decrease either, leading to the widespread references to Europe's situation as a low-employment equilibrium trap.

The second aspect of this low-level trap is displayed in figure 2, set directly below figure 1 . Since 1971, Europe's inflation rate has been about 2 percentage points higher on average than that of the United States, with the difference ranging to as much as 3 percent. ${ }^{3}$ In 1987 the difference almost vanished. After declining rapidly between 1980 and 1984, the rate of European inflation slowed only slightly more through 1987, while unemployment remained steady, indicating that Europe was operating relatively close to its NAIRU.

Table 1 displays unemployment rates in the United States, Canada, Japan, and 11 European countries for selected years spanning 1961-87.

1932-37 expansion, is containe $\rightarrow$ Sheila Bonnell, "Real Wages and Employment in the Great Depression," Economic Record, vol. 57 (September 1981), pp. 277-81. The Bonnell data and discussion were linked to Europe in the 1980s in Jeffrey D. Sachs, "Real Wages and Unemployment in the OECD Countries," BPEA, 1:1983, pp. 271-74.

3. The average annual 1971-87 inflation rate (measured by the GDP deflator) for the United States is 5.94 percent and for Europe is 7.71 percent. 
Figure 1. Unemployment Rate, United States and Europe, 1961-87

Percent

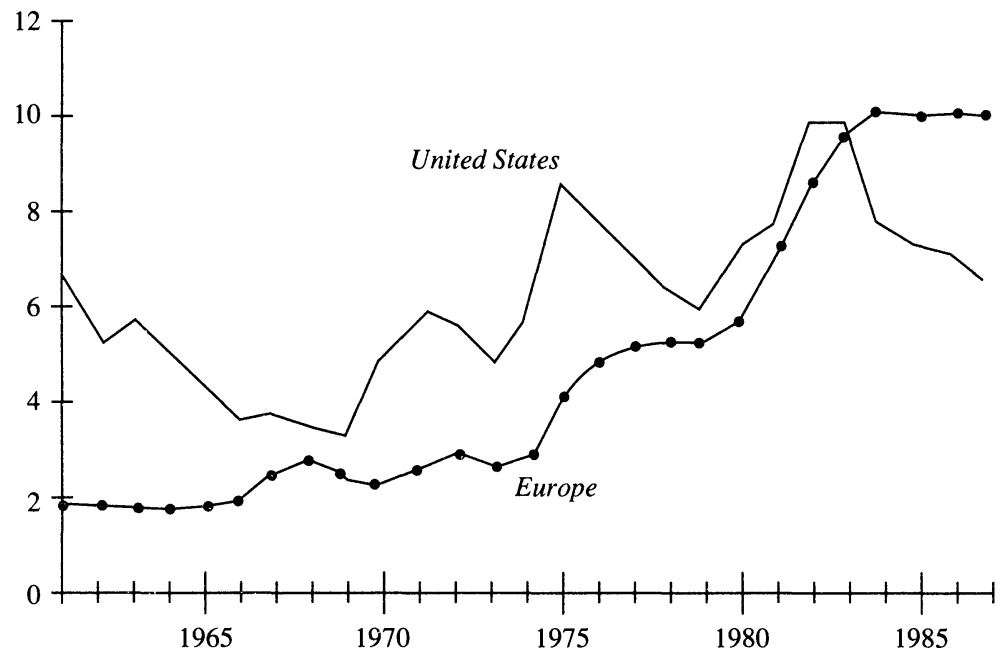

Source: OECD Economic Outlook, various issues. The unemployment rate for Europe is the total unemployment rate for 11 countries: Austria, Belgium, Denmark, France, West Germany, Italy, Netherlands, Norway, Sweden, Switzerland, and United Kingdom. For Denmark and for 1961-74 for Switzerland the data were provided by Andrew Newell of the Centre for Labour Economics at the London School of Economics. Data for 1987 are forecast data from OECD Economic Outlook, no. 42 (December 1987), table 12.

Figure 2. Inflation Rate, United States and Europe, 1961-87 a

Percent

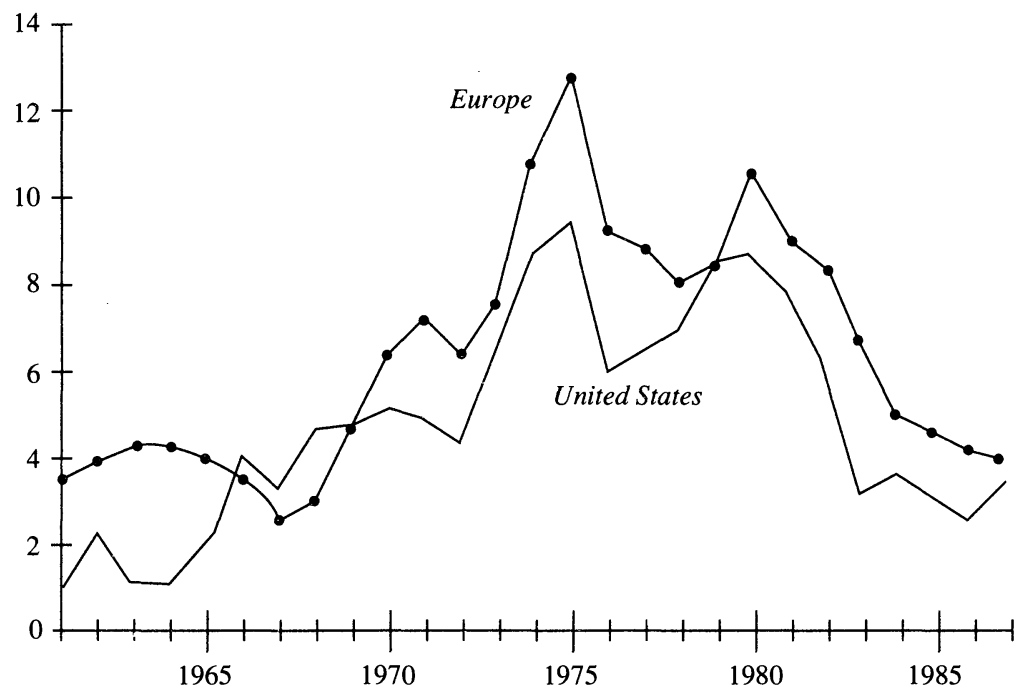

Source: OECD, National Accounts, various issues.

a. Inflation rates are the annual percentage change in the GDP deflator. 
Table 1. Standardized Unemployment Rates, Selected Countries, Selected Years, 1961-87

Percent

\begin{tabular}{lcccr}
\hline Country & 1961 & 1972 & 1979 & 1987 \\
\hline United States & 6.7 & 5.5 & 5.8 & 6.2 \\
Canada & 7.1 & 6.2 & 7.4 & 8.9 \\
Japan & 1.4 & 1.4 & 2.1 & 3.0 \\
Eleven European countries & 1.9 & 3.0 & 5.0 & 9.6 \\
France & 1.2 & 2.7 & 5.9 & 10.6 \\
Germany & 0.8 & 0.8 & 3.2 & 8.0 \\
Italy & 5.1 & 6.3 & 7.6 & 12.1 \\
United Kingdom & 1.5 & 4.0 & 5.0 & 11.0 \\
Austria & 1.9 & 1.2 & 2.1 & 3.8 \\
Belgium & 2.1 & 2.7 & 8.2 & 12.7 \\
Denmark & 1.4 & 0.9 & 5.4 & 7.9 \\
Netherlands & 0.7 & 3.1 & 5.4 & 11.0 \\
Norway & 1.5 & 1.7 & 2.0 & 2.3 \\
Sweden & 1.4 & 2.7 & 2.1 & 2.5 \\
Switzerland & 0.0 & 0.0 & 0.3 & 0.8 \\
\hline
\end{tabular}

Sources: Switzerland and Denmark, 1972 and 1979 from OECD, Labor Force Statistics 1963-83 (Paris: OECD, 1984). Other countries for 1972, 1979, and 1987: OECD Economic Outlook, no. 42 (December 1987), tables 12 and R17. All 1987 data are OECD projections. All breaks indicated in table R17 are linked using table R18, basing on 1979 levels of unemployment. All unemployment rates for 1961 are taken from International Labor Office, Yearbook of Labor Statistics, 1971 (Geneva: ILO, 1971), table 10, linked to OECD Series in 1964.

Data correspond to the standardized OECD definitions, with adjustments for data breaks and discontinuities. The European countries are divided into two groups: the four large countries, followed by the seven small countries. In 1961 and in 1972 unemployment was uniformly lower in Europe than in the United States, except for Italy in the latter year, but by 1987 unemployment was higher in Europe than in the United States in every country but the four small wunderkinder-Austria, Norway, Sweden, and Switzerland. ${ }^{4}$

4. The average 1987 unemployment rate for the 11 European countries in table 1, 9.6 percent, falls slightly short of double digits, and is lower than the average for the European Community reported in many documents and overview papers. This reflects the "northern tilt" of my selection of European countries, which includes four low-unemployment wunderkinder outside of the European Community, and which excludes the more recent members of the Community, Ireland, Spain, Portugal, and Greece, as well Finland. The choice of countries is dictated by the coverage of International Monetary Fund quarterly manufacturing data, originally developed in connection with Jacques Artus's careful research, and which subsequently has been extended to additional countries and is regularly revised by the International Monetary Fund in the form of unpublished computer printouts. $\rightarrow$ Jacques R. Artus, "The Disequilibrium Real Wage Rate Hypothesis: An Empirical Evaluation," International Monetary Fund Staff Papers, vol. 31 (June 1984), pp. 249-302. 
Table 2. Selected Economic Indicators, Europe in 1986, United States in 1939, 1941, and 1986

Index for 1986, $1972=100$; index for 1939 and $1941,1929=100$

\begin{tabular}{|c|c|c|c|c|}
\hline \multirow[b]{2}{*}{ Indicator } & \multirow{2}{*}{$\begin{array}{c}\text { United } \\
\text { States, } \\
1986\end{array}$} & \multirow{2}{*}{$\begin{array}{l}\text { Europe, } \\
1986\end{array}$} & \multicolumn{2}{|c|}{ United States } \\
\hline & & & 1939 & 1941 \\
\hline \multicolumn{5}{|l|}{ Indexes } \\
\hline 1. Output & 144.8 & 135.5 & 104.1 & 130.4 \\
\hline 2. Output per capita & 125.8 & 131.3 & 96.9 & 119.0 \\
\hline 3. Hours & 128.5 & 90.3 & 85.2 & 96.9 \\
\hline 4. Employment & 132.6 & 102.4 & 94.0 & 105.6 \\
\hline 5. Unemployment rate & 168.7 & 331.5 & 611.6 & 358.7 \\
\hline 6. Labor force & 134.6 & 109.3 & 112.3 & 113.7 \\
\hline 7. Output per hour & 112.7 & 150.0 & 122.2 & 134.6 \\
\hline 8. Real product wage & 108.2 & 149.7 & 133.3 & 139.3 \\
\hline 9. Labor's income share & 96.0 & 99.8 & 109.1 & 103.5 \\
\hline 10. Capital stock & 162.6 & 169.4 & 94.3 & 99.0 \\
\hline 11. Capital-output ratio & 112.3 & 125.1 & 90.5 & 75.9 \\
\hline 12. Capital-labor ratio & 126.5 & 187.6 & 110.7 & 102.2 \\
\hline \multicolumn{5}{|l|}{ Other } \\
\hline 13. Unemployment rate (percent) & 6.9 & 9.6 & 17.2 & 9.9 \\
\hline 14. Percent unemployed more & & & & \\
\hline than 12 months & 8.7 & 39.1 & 33.2 & n.a. \\
\hline $\begin{array}{l}\text { 15. Consumer prices (annual } \\
\text { percent change) }\end{array}$ & 2.0 & 3.8 & -0.5 & 5.0 \\
\hline
\end{tabular}

Source: Author's calculations. For columns 1 and 2, data on all lines come from author's data base. Europe refers to the 11 countries listed in table 1, with the following exceptions. Line 2, total population used to compute percapita output, comes from OECD, Labor Force Statistics, various issues. Lines 5, 13, see notes to table 1 . Line 10 for United States is based on the fixed gross nonresidential constant-dollar private capital stock, from the Survey of Current Business, vol. 67, November 1987, p. 37, table 3. Capital stock data for Europe include only France, Germany, Italy, and the United Kingdom, and come from Commission of the European Communities, Indicators of Profitability, Capital, Labour, and Output for the Non-Agricultural Business Sector, June 1986, table 11, where data displayed for 1985-86 are forecasts. Line 14 is from OECD Employment Outlook, various issues, and excludes Denmark. Line 15 from OECD Economic Outlook, no. 42 (December 1987), table R11.

Columns 3 and 4. Lines 1, 3, 4, 7, and 10, from John W. Kendrick, Productivity Trends in the United States (Princeton University Press, 1961), table A-XXII. Population used in calculating line 2 is obtained from Economic Report of the President, February 1988, table B-31, while unemployment rates and indexes on lines 5 and 13, as well as the civilian labor force on line 6, are obtained from the same source, table B-32. Line 9 is an index of labor's share from the Economic Report, table B-24, consisting of employee compensation plus 0.75 times proprietors' income with inventory valuation and capital consumption adjustments. Line 8 is line 7 times line 9 . Line 14 is from W. S. Woytinsky and Associates, Employment and Wages in the United States (New York: The Twentieth Century Fund, 1953), table 185, and refers to March 1940. Line 15 is from Economic Report, table B-62, December-toDecember for 1939, annual average for 1941 .

n.a. Not available.

Table 2 displays a selection of indicators that have figured prominently in the recent discussion of high European unemployment. The first two columns compare the United States and the 11 European countries in 1986, while the next two columns examine the United States in 1939 and 1941 , thus showing some of the dimensions of the economic expansion prior to Pearl Harbor. All the data displayed on lines 1 through 12 are 
index numbers, with 1986 numbers computed on a base $1972=100$, and the 1939 and 1941 numbers computed on a base $1929=100$.

Most of the differences between the United States and Europe in 1986 are well known, and I highlight only a few of the items in table 2. Europe's failing is in hours and employment growth, which fell short of levels in the United States by 38 and 30 index points, respectively. Europe could not have been expected to match U.S. employment growth, simply because it experienced such slow labor force growth. Between 1972 and 1986, the United States created 24 million more new jobs than did Europe. Of that total, fully 18.4 million, or 77 percent, are due to faster U.S. labor force growth, and only the remaining 5.6 million, or 23 percent, can be attributed to a failure of Europe to create sufficient jobs for its slowly growing labor force. ${ }^{5}$

The central focus of many explanations of high European unemployment is the excessive level of real wages. In 1986 Europe exceeded the United States in its product wage by slightly more than it did in output per hour, 41.5 and 37.3 index points, respectively. Over the 1972-86 period, as line 10 indicates, the capital stock grew slightly faster in Europe than it did in the United States, despite somewhat slower growth in total output and much slower growth in labor input. As a result, the growth in the capital-output ratio in Europe exceeded that in the United States by over 10 index points. Because of slow growth of labor input in Europe, the growth in its capital-labor ratio exceeded that of the United States by over 60 index points, much more than the European margin in output per hour growth.

Table 2 also points out differences between contemporary Europe and the United States in 1939. The first four lines indicate that 1939 America had an output growth problem, not just an employment problem. Total output barely exceeded that of 1929 , while output per capita, hours, and employment were all below the 1929 level. The 1939 U.S. index numbers for hours and employment are both somewhat below those for 1986 Europe, while the labor-force index (line 6) is a bit above, implying the much greater increase in unemployment displayed on line

5. The comparison between lines 4 and 6 indicates that U.S. employment growth fell 2 points short of its labor-force growth. Europe, following the same 2-point standard, would have matched the U.S. achievement with a growth in employment of 7.3 percent, or 8.4 million. Actual European employment growth was 2.8 million, for a shortfall of 5.6 million. This comparison ignores the extent to which the growth in the European labor force was slowed by high unemployment in the 1980s. 
5. The unemployment rate of 17.2 percent in 1939 America (line 13) was much higher than that in 1986 Europe, although this comparison is somewhat tempered by the dissimilar statistical treatment of government relief workers in the two periods. The productivity index for 1939 America was greatly inferior to that for 1986 Europe, although superior to that for the United States in 1986.

If economic analysts during Washington's cherry-blossom season of 1940 had enjoyed access to these 1939 data, they would have immediately noticed three impediments to American growth. First, the United States had a real wage problem, with its index of labor's income share (that is, its unadjusted wage gap) fully 9 percent higher than it was in 1929. In fact, the 1929-39 decade witnessed one of the most rapid growth rates for real wages of any decade in this century, despite the widespread joblessness. ${ }^{6}$ Not only was the wage gap index much higher in 1939 America than in 1986 Europe, but the increase in labor's share in the United States during 1929-39, 9.1 percent, exceeds the increase in the wage gap registered for Europe between 1966 and 1975 (see table 4 below).

Second, the United States appeared to suffer from a capital bottleneck, with a decline in the capital stock of more than 5 percent below the level of 1929. It would clearly have been difficult for policymakers to support expansionary demand policies with such obvious evidence of a capital shortage. In comparison, Europe in 1986 appears to have an abundance of capital, having experienced a much greater increase in the capitaloutput and capital-labor ratios than post-1972 America, which in turn had accumulated relatively more capital than the United States in the 1930s.

The third impediment to growth was long-term joblessness. Fully one-third of the unemployed had been out of work for over a year (line 14). The depreciation of human capital and skills in Europe has been interpreted as disqualifying the long-term unemployed from reemployment. If so, the same could be said of 1939 America.

The final line of table 2 reports on the consumer price inflation rate.

6. The annual rate of real wage growth in 1929-39 was 2.87 percent; in 1939-47, 2.53 percent; in 1947-57, 3.32 percent; in 1957-67, 2.65 percent; in 1967-77, 1.89 percent; and in 1977-87, 0.54 percent. Data for 1929 and 1939 are from Economic Report of the President, February 1988, and are computed by dividing total employee compensation in table B-24 by civilian employment in table B-32, and then by the implicit consumption deflator in table B-3. Data from 1947 through 1987 divide business sector compensation per hour from table B- 46 by the same implicit consumption deflator. 
Prices were virtually constant in 1939 America but increased relatively rapidly in 1941. The level of prices was on a plateau in 1939, whether measured by the consumer price index, the wholesale price index, or the GNP deflator.

\section{Eurosclerosis}

I now turn to the two competing explanations of high unemployment in Europe, based on the structuralist and hysteresis hypotheses. I group the structuralist ideas into two classes: those, known generally as "Eurosclerosis," that involve government regulation and the welfare state and those that emphasize excess real wages and the related issues of capital-labor substitution and the possibility of a capital bottleneck.

\section{SOCIAL INSURANCE AND THE WELFARE STATE}

A review of the recent literature finds little evidence to support the view that the welfare state is responsible for high European unemployment.

Unemployment Benefits. Although the conventional search theory of unemployment predicts that higher unemployment insurance replacement ratios will raise the unemployment rate, Gary Burtless has concluded that the "effect of jobless pay is far too small to explain the large rise in unemployment durations in Europe or the enormous rise of unemployment levels in Britain, France, and Germany compared with those in Sweden and the United States.' 7 James Chan-Lee and others go further, showing that replacement ratios go the wrong way as an explanation, having been reduced in a majority of OECD countries since 1980. In addition, stricter eligibility conditions have been applied in most countries, and several governments have moved to tax unemployment benefits. A particularly dramatic case is Germany, where the Chan-Lee "'macroeconomic" measure of the replacement ratio fell from 89 percent in 1970 to 26 percent in $1984 .^{8}$

7. Gary Burtless, "Jobless Pay and High European Unemployment," in Robert Z. Lawrence and Charles L. Schultze, eds., Barriers to European Growth: A Transatlantic View (Brookings, 1987), p. 155.

8. James H. Chan-Lee, David T. Coe, and Menahem Prywes, "Microeconomic Changes and Macroeconomic Wage Disinflation in the 1980s," OECD Economic Studies, no. 8 (Spring 1987), pp. 125-29. 
High Taxes and the Size of Government. Assar Lindbeck and others stress the adverse effects of the increasing share of national product spent by the government in Europe. ${ }^{9}$ For OECD Europe, government outlays as a share of GDP rose continuously from 38.3 percent in 1972 to 50.5 percent in 1983 , and stayed at that level in 1984-85. This increase of 12 percentage points was more than double the U. S. increase of 5 points (from 31.3 percent in 1972 to 36.7 percent in 1985), but only a bit more than that in Japan (22.1 percent in 1972 to 32.7 percent in 1985). ${ }^{10}$

The adverse effects of large and expanding government spending occur through various channels. One plausible channel is the tendency of European governments to rely on high employment taxes, which creates a wedge between pretax marginal product and posttax takehome pay. At one level, this is not a separate problem, but part of the issue of whether real wages are too high, since the measures of labor compensation used in most studies of the wage gap include all employment taxes. At another level, however, high marginal tax rates may create an incentive problem. They can stifle entrepreneurship, which may help to explain lagging European performance in high-technology industry and the much slower rate of growth of employment in the private service sector. High taxes may also shift economic activity to the underground economy, which may in turn lead to some understatement of European growth and overstatement of true European unemployment.

Plant Closing Legislation and Other Labor Market Regulations. Europeans love to portray themselves as trapped in webs of government regulation. Sometimes one wonders how anything gets produced at all, much less how the Germans manage to run a massive current account surplus with the United States year after year. Among the most frequently cited examples of restrictive legislation are layoff regulations, plant-closing laws, and shop-opening hours. Lindbeck is adamant that "a third prerequisite for a return to full employment in Western Europe is less regulation of the hiring and firing of labour." 11 While Europeans cite high firing costs as a source of employer unwill-

\footnotetext{
$\rightarrow$ Assar Lindbeck, "What Is Wrong with the West European Economies?" World Economy, vol. 8 (June 1985), pp. 153-70.

10. Source for government outlay shares: OECD Economic Outlook, no. 42(December 1987), table R14.

11. Lindbeck, "What Is Wrong with the West European Economies?" p. 160.
} 
ingness to hire, the theoretical effects of such costs on the unemployment rate are ambiguous, since the increase in employment costs works in one direction but the reduction in labor-force turnover works in the opposite direction. One might also note that high unemployment in Europe indicates that restrictions on layoffs and plant closings must ultimately have been ineffective.

A provocative recent study by Michael Piore debunks the usual assumption that employment security regulations are more restrictive in Europe than in the United States. Some of his conclusions are worth quoting:

The first [conclusion] is a thorough-going scepticism about the general presumption that U.S. employment arrangements are more "flexible" than European arrangements. U.S. practices are certainly different from those prevailing in European countries, but they clearly make it costly for employers to lay off and discharge workers and, in this sense, inhibit new hires. European arrangements are in fact more flexible than generally assumed and their chief impact is to delay employment adjustments and force the employers to indemnify workers. ... The variation across European countries is certainly sufficient to militate against the simple European-American comparison in terms of which the current debate has been cast. ${ }^{12}$

Piore does not discuss shop-opening restrictions, which are particularly onerous in Germany. An American visitor in German cities is startled to see the uniformity of the weeknight and early Saturday afternoon closing hours and the race of local residents to squeeze shopping into a brief time after work on weeknights. The regulations clearly inhibit the growth of convenience stores, which are a major source of jobs for American teenagers, although they do not seem to apply to fast food outlets. One suspects that these regulations, along with high marginal tax rates, are a legitimate source of the gap between productivity growth rates in the European and American service sectors, and that a weakening of the regulations would result in a closing of the gap in the direction of slower European productivity growth and more job creation at any given level of output.

Minimum Wages. Chan-Lee and others point out that there are no

12. Michael J. Piore, "Perspectives on Labor Market Flexibility," Industrial Relations, vol. 25 (Spring 1986), pp. 155-56. Robert Flanagan also argues that the contrast between the United States and Europe on employment security restrictions has been exaggerated. See Robert J. Flanagan, "Labor Market Behavior and European Economic Growth," in Lawrence and Schultze, Barriers to European Growth, pp. 193-97. 
legal minimum wages in Germany and Italy, two countries with relatively high unemployment. ${ }^{13}$ Real minimum wages fell either for all workers or for youth after 1978 in Belgium, the Netherlands, and the United Kingdom. Only in France was there a substantial increase in the real minimum wage in the $1980 \mathrm{~s}$, and the relative French minimum wage in 1985 was only 2 percent higher than it was in 1975 .

Labor Market Mismatch and Pay Compression. Some recent studies have adopted the convention of labeling any change in the NAIRU that cannot be otherwise explained as a "shift in the Beveridge curve." Because the Beveridge curve plots the vacancy rate against the unemployment rate, this expedient amounts to explaining the increase in unemployment by the increase in unemployment. If unemployment increases for some mysterious reason, and vacancies are at an irreducible minimum, one could equally well describe the economy as moving along a flat segment of the Beveridge curve. Further, absent an explicit theory of labor market dynamics, it is hard to test for shifts in the relationship as distinguished from loops that reflect dynamic adjustment.

Shifts in the Beveridge curve are supposed to provide a measure of growing labor market mismatch, that is, a greater inability of the unemployed to qualify for available jobs. Yet Robert Flanagan's examination of direct measures of structural mismatch, such as dispersion measures by industry and region, uncovers only a "small increase in measured structural mismatch." ${ }^{14}$ Flanagan prefers to stress the role of pay compression, that is, government or collective-bargaining initiatives that restrict the flexibility of relative wages, as a source of the shifting Beveridge curve. Yet Bertil Holmlund displays data on changes in wage dispersion from 1972 to 1982 that show little relation across countries to the observed increase in unemployment, while John Martin views the ambiguity of the results and inadequacies of the data as indicating a verdict of "not proven." 15

THE VERDICT ON EUROSCLEROSIS

Holmlund summed up his reaction to a recent conference on European growth with an amusing remark attributed to Erik Lundberg on some

13. Chan-Lee, Coe, and Prywes, "Microeconomic Changes."

14. Flanagan, "Labor Market Behavior," p. 187.

15. Bertil Holmlund and John P. Martin, "Comments" on Flanagan, "Labor Market Behavior,'”pp. 216, 226. 
earlier occasion, "I am afraid that this conference has not made significant progress in reducing our confusion ...., although we may be confused at a higher level." 16 I would go further and say that the failure of structuralists to come up with convincing explanations of high European unemployment has reduced our confusion. When one sees so many people grasping at so many straws, one is naturally led to skepticism about the structuralist approach.

Discussions of Eurosclerosis tend to assume that Europe's experience with big government is unique; it has, however, a direct antecedent in the experience of 1939 America, where a wave of New Deal legislation had legitimized unions, regulated wages and hours, and initiated the federal social security and unemployment compensation systems. Some analysts of that period have attributed the failure of U.S. investment to revive in the late 1930s to uncertainty about the scope of future government programs and the anticipation of lower after-tax returns to capital. ${ }^{17}$ Just as these fears are a distant antecedent of those attending Europe's current plight, the 1939-41 expansion demonstrates that many perceived obstacles can fade away in the face of a strong demand expansion.

\section{Real Wages, the Wage Gap, and Labor-Capital Substitution}

Most structuralist interpretations of high European unemployment stress not only Eurosclerosis, but also the role of high real wages and the wage bargaining process.

\section{REAL WAGES AND THE WAGE GAP: CONCEPTUAL ISSUES}

Jean Waelbroeck claims that "it is the institutional changes that have shifted the balance of power between employers and employees that are at the root of the trouble." 18 Lindbeck blames "increased costs and inflexibilities in labour markets" and "the increased inability of both real and relative wage rates to equilibrate various parts of the labour

16. Ibid., p. 217.

17. See especially Allan H. Meltzer, "Comments on 'Monetarist Interpretations of the Great Depression,' ' ' in Karl Brunner, ed., The Great Depression Revisited (Martinus Nijhoff, 1981), pp. 153-56.

18. Jean Waelbroeck, "Macroeconomic Issues for Europe in the 1980s: or Can the NAIRU Be Tamed?' 'in Herbert Giersch, ed., Macro and Micro Policies for More Growth and Employment (Kiel Symposium, forthcoming), quote from conference draft, p. 10. 
market." 19 The comprehensive review of the West German situation by Rudiger Soltwedel and Peter Trapp concludes that the "readiness of the government to tackle or to relieve employment problems in combination with the monopolistic features of the wage bargaining system in West Germany !ed to a pronounced real wage rigidity." ${ }^{20}$

However, there is a growing realization among critics that neither data on the real wage nor data on the "wage gap," the index of labor's income share, have unique implications for unemployment. ${ }^{21}$ As Paul Krugman and other recent critics have stressed, an increase in the wage gap is neither necessary nor sufficient to demonstrate the existence of classical unemployment. ${ }^{22}$ Here I summarize some of the issues, and relate the wage gap debate to the issue of a possible capital shortage in Europe.

If the production function is Cobb-Douglas, with a unitary elasticity of substitution between capital and labor, excess real wages can cause unemployment without causing a change in labor's income share, since higher wages completely pay for themselves by boosting labor's average product exactly in proportion. Hence, a higher wage gap is not necessary to demonstrate the existence of classical unemployment. Proponents of wage gap analysis reconcile the Cobb-Douglas assumption with the increases in European wage gap indexes between the mid-1960s and mid-1970s by noting the possibility of a temporary disequilibrium in the immediate aftermath of an increase in the real wage, prior to the substitution of capital for labor. ${ }^{23}$

19. Lindbeck, "What Is Wrong with the West European Economies?" p. 155.

20. Rudiger Soltwedel and Peter Trapp, "Labor Market Barriers to More Employment: Causes for an Increase of the Natural Rate? The Case of West Germany," in Giersch, Macro and Micro Policies, quotation from manuscript, p. 44.

21. The use of wage gap indexes to explain high European unemployment was popularized in a series of papers by Michael Bruno and Jeffrey D. Sachs, culminating in their book Economics of Worldwide Stagflation (Harvard University Press, 1985). Two important earlier papers were Sachs, "Wages, Profits, and Macroeconomic Adjustment: A Comparative Study," BPEA, 2:1979, pp. 269-319; and Sachs, "Real Wages and Unemployment."

22. See, for example, Paul R. Krugman, "Slow Growth in Europe: Conceptual Issues," in Lawrence and Schultze, Barriers to European Growth, pp. 48-93.

23. A diagrammatic version of this analysis appears in Charles L. Schultze, "Real Wages, Real Wage Aspirations, and Unemployment in Europe," in Lawrence and Schultze, Barriers to European Growth, p. 241. The Schultze diagram is particularly useful because it is set up in logs, allowing the Cobb-Douglas case to be portrayed in a simple way. 
This framework does not deny the possibility that aggregate demand can play a role in unemployment. If firms cannot sell all they want, they can operate off their production function and "notional" (that is, marketclearing) labor demand curve. The wage gap in such a situation cannot be determined until we specify how output adjusts with movements of employment away from the notional demand curve. With short-run increasing returns, labor's average product falls and the wage gap increases from its long-run value; with short-run diminishing returns, the opposite occurs.

Why is a change in the wage gap not sufficient to demonstrate classical unemployment? First, with short-run increasing returns the wage gap might increase even though unemployment is entirely Keynesian. This possibility led Michael Bruno and Jeffrey Sachs to create an adjusted wage gap concept, with labor's average product defined as the fullemployment value, which in practice meant that historical values of labor productivity were adjusted for typical cyclical fluctuations. Second, and more important, the production function might not be CobbDouglas. With an elasticity of substitution between labor and capital below unity, the normal process of capital accumulation would be expected gradually to raise labor's share and measured wage gap indexes. Charles Schultze has used aggregate data for the United States and four large European countries to estimate the elasticity of factor substitution; for the aggregate business sector he obtains values of unity for Germany and the United Kingdom, and values of between 0.66 and 0.73 for France, Italy, and the United States. ${ }^{24}$ However, as Jacques Artus points out, increases in capital intensity were larger during the 1960 s, when there were small changes in labor's share, than during the 1970s, when most of the increase in labor's share took place..$^{25}$ One might counter to both Artus and Schultze that labor's share has declined significantly in Europe since 1978, yet capital accumulation has proceeded apace. With an increase in the capital-labor ratio since 1972 of almost 90 percent (table 2 , line 12), an elasticity of substitution as low as 0.7 would have created a substantial and continual increase in labor's share, in contrast with the modest increase that was subsequently reversed in full.

24. Schultze, "Real Wages," in Lawrence and Schultze, Barriers to European Growth, table 2, p. 249.

25. Jacques R. Artus, "Comment," on Schultze, "Real Wages," in Lawrence and Schultze, Barriers to European Growth, pp. 292-95. 
EVIDENCE ON PRODUCTIVITY, WAGES, AND PRICES

The interpretation of the decline in the wage gap as a correction of disequilibrium seems to rest on a highly implausible delay in adjustment, given that the most important episode of real wage "push" occurred in Europe between 1968 and 1970, almost 20 years ago. To provide a more concrete interpretation, I attempt now to allocate movements of labor productivity among the effects of labor hoarding and other cyclical responses, deviations of real wage movements from the "true" underlying productivity trend, and that trend itself. I find indeed that strong substitution effects away from labor in most European countries during 1968-78 reduced labor input relative to output, but that these effects were largely reversed after 1978. An interesting implication of these findings is that the slowdown in European productivity growth in the 1980s results entirely from the cyclical and real wage effects, with no statistically significant slowdown in the underlying productivity trend in any of the 11 European countries.

Extracting the Productivity Trend. As noted, with a Cobb-Douglas production function, excess growth in real wages could pay for itself with faster productivity growth, leaving no evidence in the wage gap data of any problem of classical unemployment. To supplement studies by others that have provided direct estimates of the elasticity of substitution, here I take the shortcut of estimating directly the response of the change in labor input to changes in the real wage.

The basic specification relates the log ratio of hours to trend output $\left(N_{t}-Q_{t}^{*}\right)$ to the log output ratio $\left(Q_{t}-Q_{t}^{*}\right)$, representing the cyclical effect of output on hiring decisions, to the real wage rate defined relative to the underlying productivity trend $\left[\left(W_{t}-P_{t}\right)-\theta_{t}^{*}\right]$, which could differ from zero as a result of excess growth in the real wage; and to the productivity trend itself $\left(\theta_{t}^{*}\right)$. With all uppercase letters defined as logs of levels, write:

$$
\left(N_{t}-Q_{t}^{*}\right)=A+\phi\left(Q_{t}-Q_{t}^{*}\right)-\sigma\left(W_{t}-P_{t}-\theta_{t}^{*}\right)-\theta_{t}^{*},
$$

where $A$ is a constant. Note that equation 1 adds a cyclical effect to a standard static labor demand function in which labor hours depend on the real wage and on labor-augmenting technical progress. The trend in equation 1 picks up the effects of growth in the capital-labor ratio and of changes in other inputs. 
When equation 1 is rewritten as an equation for the average product of labor $(Q / N)$, the parameter $\phi$ can be interpreted as indicating the effect of cyclical movements in the output ratio on labor productivity:

$$
\left(Q_{t}-N_{t}\right)=-A+(1-\phi)\left(Q_{t}-Q_{t}^{*}\right)+\sigma\left(W_{t}-P_{t}-\theta_{t}^{*}\right)+\theta_{t}^{*} .
$$

If the parameter $\phi$ is unity, then a permanent increase in the output ratio has no impact on actual labor productivity, whereas a value of $\phi$ below unity implies a permanent productivity gain (short-run increasing returns), and a value of $\phi$ above unity implies a permanent productivity loss (short-run diminishing returns).

Equation 1 permits a wage gap concept adjusted not just for cyclical effects but for the endogenous response of productivity growth to excess growth in the real wage. With $\Theta$ defined as the log level of labor's actual average product and $\theta^{*}$ defined as the growth rate of the trend in labor's average product, the actual wage gap index $\left(W G_{t}\right)$ can be written as $W_{t}-P_{t}-\Theta_{t}$ and the adjusted wage gap index $\left(W G_{t}^{*}\right)$ as $W_{t}-P_{t}-\theta_{t}^{*}$. Equation 2 can then be rearranged to obtain:

$$
W G_{t}=A-(1-\phi)\left(Q_{t}-Q_{t}^{*}\right)+(1-\sigma)\left(W G_{t}^{*}\right) .
$$

If the elasticity of labor input with respect to the excess real wage $(\sigma)$ in equation 1 is unity, then equation 3 shows that the excess real wage growth pays for itself by boosting actual productivity enough to keep the actual wage gap index $\left(W G_{t}=W_{t}-P_{t}-\Theta_{t}\right)$ unaffected. Only if the elasticity $(\sigma)$ is less than unity is excess real wage growth manifested in an increase in the observed actual wage gap index.

Equation 1 could be estimated either in levels or in growth rates. Initial testing indicated that the growth rate specification is superior, avoiding the serial correlation that occurs with the level specification for some countries. With lags and a post-1972 break in the productivity growth trend, equation 1 becomes:

$$
\left(n-q^{*}\right)_{t}=\sum_{j=0}^{1} \phi_{j}\left(q-q^{*}\right)_{t-j}-\sum_{k=0}^{1} \sigma_{k}\left(w-p-\sum_{i=0}^{1} \theta_{i}^{*}\right)_{t-k}-\sum_{i=0}^{1} \theta_{i}^{*},
$$

where $\theta_{0}^{*}$ is the $1964-72$ productivity trend and $\theta_{1}^{*}$ is the 1973-84 productivity trend. To unscramble the productivity trends from the estimated regression, the equation is run in the form:

$$
\left(n-q^{*}\right)_{t}=\sum_{j=0}^{1} \phi_{j}\left(q-q^{*}\right)_{t-j}-\sum_{k=0}^{1} \sigma_{k}(w-p)_{t-k}-\sum_{i=0}^{1} \alpha_{i}+\epsilon_{t},
$$




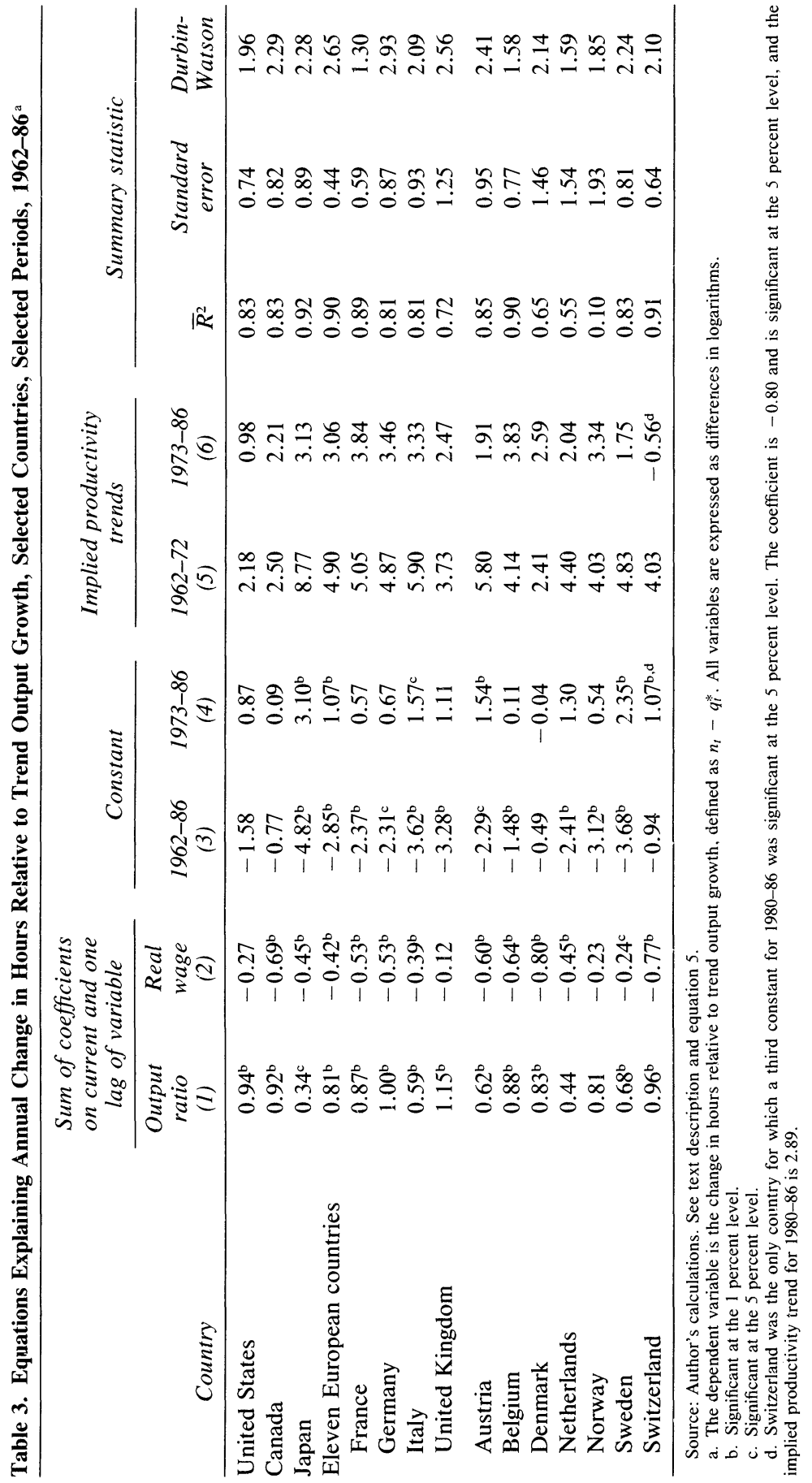


where $\alpha_{0}$ is the constant term (equal to unity for 1964-86) and $\alpha_{1}$ is a dummy variable (equal to zero for 1964-72 and to unity for 1973-86). Then the productivity trend terms are defined as:

$$
\theta_{0}^{*}=\frac{-\alpha_{0}}{1-\sum_{k} \sigma_{k}} ; \quad \theta_{1}^{*}=\frac{-\left(\alpha_{0}-\alpha_{1}\right)}{1-\sum_{k} \sigma_{k}} .
$$

In preliminary tests an additional productivity term $\left(\alpha_{2}\right.$ equal to unity during 1980-86) was entered to test for the significance of a second growth slowdown after 1979, but this term was uniformly insignificant in the presence of the real wage variable except for Switzerland, as shown in table 3.

Estimated Productivity Equations. Results for the productivity regression equations for the 14 countries are presented in table 3 . All sums of coefficients on the output ratio are between zero and unity except for the United Kingdom, indicating almost uniformly procyclical behavior of productivity. ${ }^{26}$ Only the United Kingdom exhibits a countercyclical effect; the United States, Canada, France, Belgium, and Switzerland exhibit a mildly procyclical effect; procyclical effects are stronger for Japan, Italy, Austria, and Sweden. The GNP-weighted aggregate of all 11 European countries shows that the labor hoarding, or procyclical productivity, phenomenon is somewhat more important in Europe than in the United States.

The real wage elasticities have the correct negative sign and are statistically significant in all the countries but the United States, the United Kingdom, and Norway. Most of the elasticities are between -0.4 and -0.6 , indicating that an increase in wages relative to the productivity trend, for whatever reason, boosts productivity enough to offset about half but not all of the resulting upward pressure on the wage gap. There seems to be no connection between the real wage elasticity and the post- 1970 rise in unemployment. Relatively high elasticities are found for countries with both high and low unemployment rates in the

26. For each country I need an estimate of the log capital-output ratio (or output gap). As in previous papers, I have set potential or "natural" output equal to actual output in three benchmark years, 1961 (1964 in Canada, the United States, and France), 1972, and 1979. I have dropped my previous practice of extending the post-1979 growth trend at the 1972-79 observed rate. Instead, I have adopted Schultze's more conservative output gap estimates for 1985, based on his careful study of country-by-country trends in the capitaloutput ratio, and have constructed the 1979-86 trend in natural output to achieve the Schultze output gap measure in 1985. (Schultze has capital stock data only on the four large European countries.) 
1980s. Interestingly, the elasticity for Europe as a whole is almost identical to that for Japan.

Table 3 displays in columns 3 and 4 the $\alpha$ coefficients that must be unscrambled, using equation 6 , to reveal the underlying structural productivity trends $\left(\theta^{*}\right)$, and the resulting trends are shown separately in columns 5 and 6 . The productivity coefficients in column 5 are useful as an indication of the statistical significance of the post-1972 slowdown in productivity growth. Somewhat surprisingly, the slowdown terms in column 4 of table 3 are significant only for a minority of countries, largely because my equations place weight on a slowdown in real wage growth in the late 1970s and 1980s as an explanation of slower productivity growth. The test of a second productivity slowdown after 1979 yields insignificant terms for every country but Switzerland, which exhibits a productivity growth revival after 1979.

Implied Wage Gap Indexes. Adjusted wage gap indexes $\left(W G_{t}^{*}\right)$ defined for the estimated productivity trends are presented for the European aggregate and the United States in figure 3. Europe's adjusted wage gap increased 8.5 percentage points between 1966 and 1978 and then fell 8.0 points between 1978 and 1986. The graph displays a clear difference between Europe and the United States in the timing of changes in the adjusted wage gap, with a large increase for Europe between 1969 and 1975 , followed by a plateau during 1975-80 and an extremely rapid decline after 1980. For the full 1963-86 period, there appears to be no evidence of excess real wage growth in Europe as contrasted with the United States.

The individual country data in table 4 throw cold water on the wage gap as an explanation of cross-country differences in unemployment rates or unemployment changes. High-unemployment Netherlands has a high real wage gap, but so do low-unemployment Austria and Switzerland. Belgium's real wage gap has faded away with remarkable speed. The four large European countries all have adjusted wage gap indexes close to or below the American level. These results have the advantage, compared with most other wage gap presentations, of taking account, at least in part, of the endogenous response of productivity to excess real wage movements.

Implications for the Capital Shortage Issue. A shortage of available capacity is often cited as an obstacle to demand stimulus in Europe. By 1986 manufacturing capacity utilization in the four large European 
Figure 3. Wage Gap Indexes, United States and Europe, 1961-86

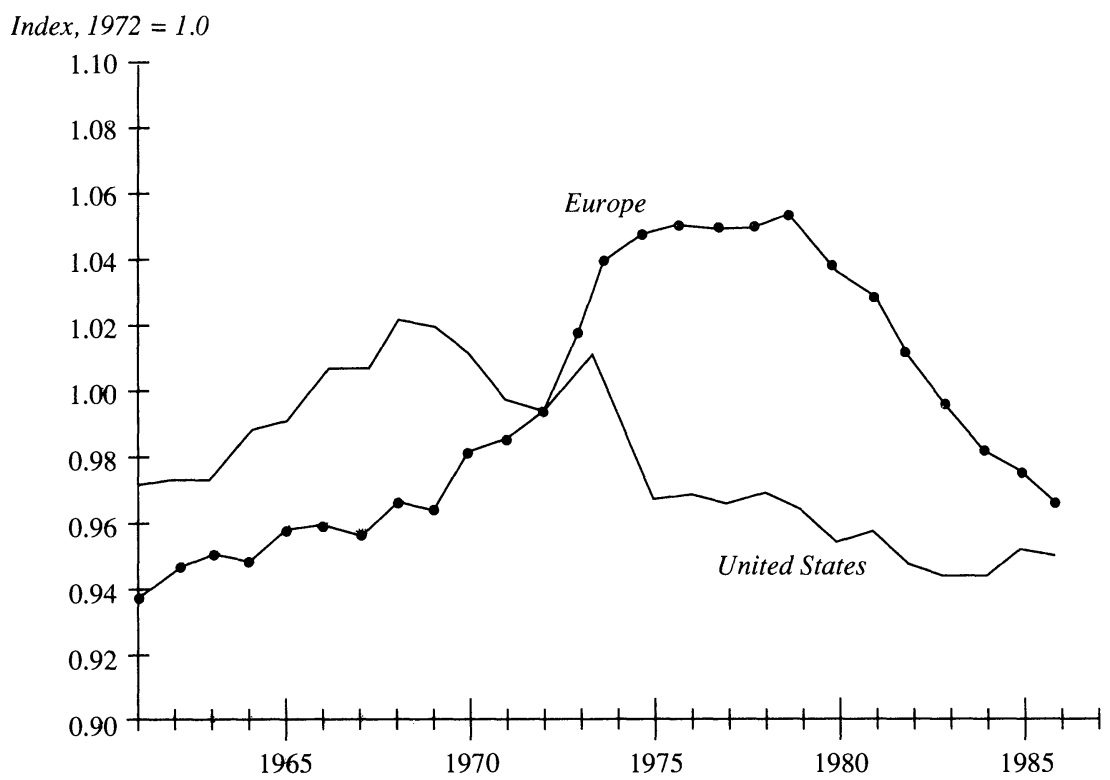

Source: Author's calculations. See text description and table 4 .

Table 4. Wage Gap Based on Trend Productivity, Selected Years, 1963-86

Index, $1972=1.0$

\begin{tabular}{lccccccccc}
\hline Country & 1963 & 1966 & 1969 & 1972 & 1975 & 1978 & 1981 & 1984 & 1986 \\
\hline United States & 0.975 & 1.010 & 1.021 & 1.000 & 0.972 & 0.974 & 0.961 & 0.946 & 0.953 \\
Canada & 0.906 & 0.938 & 0.967 & 1.000 & 0.995 & 0.987 & 0.926 & 0.916 & 0.894 \\
Japan & 1.035 & 0.997 & 0.997 & 1.000 & 1.146 & 1.120 & 1.095 & 1.068 & 1.063 \\
Eleven European & & & & & & & & & \\
$\quad$ countries & 0.956 & 0.965 & 0.970 & 1.000 & 1.048 & 1.050 & 1.037 & 0.987 & 0.970 \\
France & 0.973 & 0.986 & 0.988 & 1.000 & 1.071 & 1.076 & 1.057 & 1.036 & 0.979 \\
Germany & 0.940 & 0.958 & 0.973 & 1.000 & 1.031 & 1.016 & 1.007 & 0.940 & 0.926 \\
Italy & 0.956 & 0.960 & 0.970 & 1.000 & 1.015 & 0.989 & 0.954 & 0.884 & 0.874 \\
United Kingdom & 0.962 & 0.960 & 0.940 & 1.000 & 1.025 & 0.984 & 0.983 & 0.941 & 0.947 \\
Austria & 0.962 & 0.971 & 0.992 & 1.000 & 1.156 & 1.194 & 1.276 & 1.228 & 1.252 \\
Belgium & 0.838 & 0.883 & 0.892 & 1.000 & 1.127 & 1.122 & 1.113 & 1.002 & 0.936 \\
Denmark & 0.776 & 0.835 & 0.944 & 1.000 & 1.056 & 1.110 & 1.080 & 1.058 & 0.992 \\
Netherlands & 0.826 & 0.870 & 0.938 & 1.000 & 1.185 & 1.373 & 1.273 & 1.249 & 1.228 \\
Norway & 0.890 & 0.898 & 1.000 & 1.000 & 1.068 & 1.093 & 0.926 & 0.883 & 0.929 \\
Sweden & 1.039 & 1.030 & 1.040 & 1.000 & 1.026 & 1.081 & 1.013 & 0.923 & 0.905 \\
Switzerland & 0.992 & 0.976 & 0.970 & 1.000 & 1.152 & 1.192 & 1.263 & 1.212 & 1.193 \\
\hline
\end{tabular}

Source: Author's calculations based on equations in table 3. See text description. 
countries had come within a percent or two of matching previous peaks reached in 1973 and 1979.27 This indicates that manufacturing capacity grew between 1979 and 1986 at about the same rate as manufacturing output and that actual capacity falls far short of full-employment capacity. Yet my productivity results cast doubt on the capital shortage hypothesis. The ratio of capital to output in Europe in 1986 was 25 percent higher than it was in 1972, whereas in the United States the capital-output ratio was just 12 percent higher (table 2, line 11). Because by 1986 excess European real wage growth had disappeared, as measured by the adjusted wage gap in table 4, essentially none of the ongoing accumulation of capital in Europe in the 1980s can be interpreted as a result of substitution away from labor in response to excess real wage growth. Instead, the data favor the interpretation that Europe has ample capital to support a demand expansion sufficiently rapid to bring down the unemployment rate. The output growth record of the U.S. economy between 1939 and 1941, despite a measured decline in the capital stock from 1929 to 1939 , stands as a precedent that sheds doubt on the capital bottleneck argument.

\section{Hysteresis and the Floating NAIRU}

The experience of Europe in the past decade raises serious doubts about the inertial version of the natural rate hypothesis that has figured prominently in discussions of postwar U.S. unemployment. This view implies that inflation is constant when unemployment or output is at its natural rate, decelerates when unemployment is above its natural rate, and accelerates when unemployment is below its natural rate. Inflation is linked to its own past history by inertia, and upward or downward pressure is exerted on today's inflation rate relative to the inherited inertial inflation rate by high or low product demand and low or high unemployment.

The inertial version of the natural rate hypothesis displays impressive stability and predictive power in the postwar United States and in some historical eras, but it falls apart in two crucial episodes-for the United

27. Franco Modigliani and others, "Reducing Unemployment in Europe: the Role of Capital Formation," in Richard Layard and Lars Calmfors, eds., The Fight Against Unemployment: Macroeconomic Papers from the Centre for European Policy Studies (MIT Press, 1987), figure 2, p. 17. 
States in 1919-41 and the United Kingdom in 1922-38. It falls apart in postwar Europe in much the same way. The natural rate theory predicts that unemployment above the natural rate leads to an "accelerating deflation," that is, ever lower inflation with an ever-increasing absolute difference between this period's and last period's inflation. But an accelerating deflation has never been observed. At the climax of the great deflation of the late nineteenth century in the United States, during the depression of the $1890 \mathrm{~s}$, there was no hint of acceleration in the rate of defiation. ${ }^{28}$ Nor did the gap between actual and natural unemployment in the United States after 1933 exert downward pressure on inflation.

Today almost all discussions of European unemployment are carried on in terms not of the natural rate but of the nonaccelerating inflation rate of unemployment (NAIRU). As shown in figure 2 above, European inflation has reached a plateau and is no longer decelerating, despite unemployment of roughly 10 percent. The conclusion reached by most studies is that the NAIRU must therefore have crept inexorably upward from its early 1970s value of 2 or 3 percent toward today's actual unemployment rate of roughly 10 percent..$^{29}$ Europe is in equilibrium, with inflation neither accelerating nor decelerating, and thus there is no room for demand expansion.

The relationship between the upward-creeping NAIRU and the hysteresis hypothesis is best discussed in terms of a specific model. ${ }^{30} \mathrm{~A}$ general Phillips curve can be written as:

$$
p_{t}=p_{t-1}-a\left(U_{t}-U_{t}^{*}\right),
$$

28. For six straight years, 1893 through 1898 , real GNP remained below trend by an average amount of 7.5 percent; see Nathan S. Balke and Robert J. Gordon, "Appendix B: Historical Data," in Robert J. Gordon, The American Business Cycle: Continuity and Change (University of Chicago Press, 1986), p. 782. According to Albert Rees, Real Wages in Manufacturing, 1890-1914 (Princeton University Press, 1961), table 22, p. 74, prices fell at an annual rate of 2.7 percent between 1892 and 1895 but at an annual rate of only 0.4 percent between 1895 and 1898 .

29. Among the many studies reporting inexorably rising NAIRUs for individual countries are Richard Layard and others, "Europe: The Case for Unsustainable Growth," in Olivier Blanchard, Rudiger Dornbusch, and Richard Layard, eds., Restoring Europe's Prosperity: Macroeconomic Papers from the Centre for European Policy Studies (MIT Press, 1986), pp. 33-94; David T. Coe and Francesco Gagliardi, "Nominal Wage Determination in Ten OECD Economies," Working Paper 19 (OECD, March 1985); and Schultze, "Real Wages."

30. This discussion is adapted from Charles Wyplosz, "Comments," on Wolfgang Franz, "Hysteresis, Persistence, and the NAIRU: An Empirical Analysis for the Republic of Germany," in Layard and Calmfors, The Fight Against Unemployment, pp. 123-31. 
where $p$ is the rate of inflation and $U$ is the rate of unemployment. The NAIRU, $U^{*}$, corresponds to the steady-state situation when $p_{t}=p_{t-1}$. The value of the NAIRU depends on a set of microeconomic labor market determinants, say $U_{t}^{*}=b Z_{t}$, where $Z_{t}$ is a vector of relevant microeconomic variables, such as the replacement ratio of the unemployment compensation system.

Hysteresis can arise when $U_{t}^{*}$ depends in addition on past unemployment rates, as in:

$$
U_{t}^{*}=c U_{t-1}+b Z_{t} .
$$

Substituting equation 8 into equation 7 results in:

$$
p_{t}=p_{t-1}-a\left(U_{t}-c U_{t-1}\right)+a b Z_{t} .
$$

Hysteresis occurs when $c$ equals unity, implying that there is no longer a unique NAIRU. If $c$ is less than unity, there is still a unique NAIRU, $U^{*}=b Z /(1-c)$.

This framework helps to distinguish the two main approaches to the explanation of European unemployment. Those who attempt to implement the structuralist approach econometrically model the upwardcreeping NAIRU as a function of explicit time series proxies for $Z_{t}$. Richard Layard and Stephen Nickell provide a decomposition of the increase in U.K. unemployment among such factors as labor taxes, the replacement ratio, union militancy, real import prices, and labor market mismatch. ${ }^{31}$ Other studies provide no detailed breakdown of the increase in the NAIRU but assume that something must have occurred in labor markets to cause a structural change, that is, that some unobserved $Z_{t}$ variable must have increased. This structuralist approach yields pessimistic policy conclusions: some microeconomic $Z$ factors, specified or unspecified, have caused the NAIRU to increase to the level of today's actual unemployment rate. Any demand expansion would thus, by the standard NAIRU theory, lead to only a temporary reduction in unemployment but to a permanent acceleration of inflation.

By contrast, the hysteresis hypothesis states that most or all of the

31. Richard Layard and Stephen J. Nickell, "Unemployment in Britain," Economica, vol. 53 (Supplement 1986), pp. S121-69. A similar but less detailed decomposition for all OECD countries is provided in C. R. Bean, P. R. G. Layard, and S. J. Nickell, "The Rise in Unemployment: A Multi-Country Study," Economica, vol 53 (Supplement 1986), pp. S1-22. 
increase in the NAIRU in equation 8 may have been contributed by the lagged unemployment terms, without any increase in $Z_{t}$ at all. If $Z_{t}$ has not increased, and if $c$ equals unity, the policy implications are completely different. A demand expansion that reduces the rate of unemployment would reduce the NAIRU the same amount. The hysteresis approach does not claim that expansion can be pulled off without any added inflation. As is evident in equation 9, hysteresis with $c$ equal to unity is observationally equivalent to a Phillips curve in which only the change in unemployment rather than its level matters, except for the $a b Z_{t}$ term. If $a$ is greater than zero, then steady inflation can occur with steady unemployment only if $b$ is equal to unity, which implies in equation 2 that there is no structural component to the NAIRU at all. When unemployment decreases, inflation increases, and the permanent acceleration of inflation depends only on the value of the $a$ coefficient. Starting from an initial inflation rate $p_{0}$, the inflation rate $\left(p_{n}\right)$ that occurs after $n$ periods of changing unemployment is:

$$
p_{n}=p_{0}-a \sum_{i=1}^{n} \Delta U_{i}
$$

This result assumes that the coefficient on lagged inflation is unity. As we shall see, a major difference between U.S. interwar inflation and both postwar European and postwar U.S. inflation is that in the former case the coefficient of current inflation on lagged inflation is a fraction $0<j<1$. With $b$ equal to zero, the steady-state inflation rate in this case is $p_{t}=\left(-a \Delta U_{t}\right) /(1-j)$, which is equal to zero when unemployment settles down at any constant level.

The permanent acceleration of inflation associated with demand expansion in the case where the coefficient on lagged inflation is unity $(j=1)$, relevant for contemporary Europe, creates a welfare trade-off and requires an explicit analysis to assess the conflict between the permanent increase in inflation and a permanent gain in output and employment. This analysis, which differs from the usual welfare analysis with a fixed natural rate, has been carried out by Sachs. ${ }^{32}$ His model, like that discussed here, generates the result that a permanent reduction

32. Jeffrey Sachs, "High Unemployment in Europe: Diagnosis and Policy Implications," in Claes-Henric Siven, ed., Unemployment in Europe: Analysis and Policy Issues (Timbro, 1987), pp. 7-38. 
in unemployment generates a permanent but fixed (that is, nonaccelerating) increase in inflation, while a permanent increase in unemployment generates a permanent but fixed decrease in inflation. By adding to the model a welfare function in which higher inflation and unemployment both decrease welfare, he reaches the intuitively appealing conclusion that the optimal policy depends on the starting place. With initially high inflation and low unemployment, policy should raise the unemployment rate to lower permanently the inflation rate. With initially low inflation and high unemployment, policy should reduce the unemployment rate and accept the permanent increase in the inflation rate.

\section{EXPLANATIONS FOR HYSTERESIS}

The essence of the hysteresis hypothesis, as stated formally in a simple model like that outlined above, is that no government policy action is needed to reduce the NAIRU. Demand sufficient to reduce the actual unemployment rate will automatically reduce the NAIRU. As equation 10 states, today's inflation is related to inflation at any past date by the cumulative change in unemployment since that date; all that is necessary to relive the past is to create a change in unemployment that reverses whatever has happened in the past. When the influence of supply shocks is added to equation 10 , the past can be relived only if supply shocks have balanced out-if, for example, adverse oil shocks have been followed by equally beneficial oil shocks.

Proponents of hysteresis have offered numerous theoretical explanations, of which three-disappearance of physical capital, decay of human capital, and the "insider-outsider" distinction-dominate the literature. At least on the surface, the most plausible explanation is a lack of capital, although I have argued above that Europe is amply endowed with capital. The other two explanations of hysteresis focus on the labor market. The human capital argument is that in a "lowpressure" economy, skills and knowledge are lost, while a high-pressure economy works in reverse, creating higher labor-force participation and valuable initial contact with the labor market for underprivileged or lowskill people. ${ }^{33}$

33. A classic statement of the human capital argument applied in reverse, to a world of low unemployment rather than high unemployment, is Arthur M. Okun, "Upward Mobility in a High-Pressure Economy," BPEA, 1:1973, pp. 207--52. Further discussion of the human capital argument is contained in Blanchard and Summers, "Hysteresis," pp. $28-29$. 
The insider-outsider model has been proposed by Assar Lindbeck and Dennis Snower and by R. G. Gregory, and it has been extended and promoted by Olivier Blanchard and Lawrence Summers. ${ }^{34}$ In its simplest and most extreme version, wage setting is entirely determined by existing employees, the insiders; the unemployed exert no downward pressure on wages at all. The insiders care only about remaining employed and set the wage at the level that will maintain the existing level of employment. This mechanism means that any level of employment is selfsustaining.

In my view, the theories developed thus far to explain hysteresis rely excessively on mechanisms that imply barriers to growth. Yet history provides numerous examples of rapid growth in output and employment after long periods of high unemployment when capital and skill deterioration must have been even more severe than in Europe today. Table 2 documents the record for the U.S. economy in 1939-41, starting from a situation with one-third of the unemployed out of work for more than a year, and that table shows how rapidly output was able to grow with only a minimal addition of capital. Britain enjoyed a brisk noninflationary expansion during 1932-38 without apparent bottlenecks. On several occasions before the 1930s the U.S. economy grew extremely rapidly after a long period of slow growth. The annual growth rate of real GNP in 1872-76 was 1.8 percent; in 1876-82, 7.2 percent; in 1892-96, 0.3 percent; in 1896-1901, 6.7 percent. A full decade of 0.4 percent annual growth during 1911-21 was followed by a 7.6 percent spurt during 192126.

How, then, to explain hysteresis? I prefer to rephrase the question: why does the Phillips curve mechanism sometimes work through the rate of change of demand (unemployment or the output gap) instead of through the level of demand? A more precise description of the empirical puzzle is that the rate-of-change effect is always present; what is unique about the U.S. Depression and contemporary Europe is not the sudden appearance of the rate-of-change effect, but rather the disappearance of the level effect, that is, the failure of prolonged high unemployment to exert continuing downward pressure on the rate of change of wages and prices.

34. Assar Lindbeck and Dennis J. Snower, "Wage Setting, Unemployment, and Insider-Outsider Relations," American Economic Review, vol. 76 (May 1986, Papers and Proceedings, 1985), pp. 235-39; R. G. Gregory, "Wages Policy and Unemployment in Australia," Economica, vol. 53 (Supplement 1986), pp. S53-74; Blanchard and Summers, "Hysteresis." 
That the level effect disappears whenever high unemployment persists suggests that the level effect is not a true structural phenomenon. The rate-of-change effect is structural: wage demands moderate when unemployment is rising because the employed fear for their jobs, and wage demands accelerate when unemployment falls because some employers are forced to raise wages to attract new workers and keep old ones from quitting. ${ }^{35}$ Similarly, firms raise the level of markups when the level of demand is high, reinforcing the relation between the rate of change of prices and the rate of change of demand. The mystery is not the rate-ofchange effect itself, but why there should be a level effect at all. It remains to be seen whether there is room to salvage the level effect by invoking an asymmetry that the level effect works continuously through prolonged periods of high demand but peters out in prolonged periods of low demand.

\section{THE HYSTERESIS EFFECT IN PRICE AND WAGE EQUATIONS}

No consensus has emerged on the empirical importance of hysteresis in contemporary Europe. Blanchard and Summers estimate an equation like equation 9 directly, using the employment rate and unemployment rate as alternatives, and using the change in wages rather than change in prices as the dependent variable. They find values of $c$ close to unity in France, Germany, and Italy, but not in the postwar United States, and they also obtain $c$ values of unity for the interwar United States. In contrast, ambiguous or negative verdicts on the hysteresis hypothesis for major European countries have been obtained in other studies. ${ }^{36}$ Below I provide new estimates that strongly support Blanchard and Summers, yielding pure hysteresis inflation equations for both postwar Europe and for the interwar United States.

35. George L. Perry has outlined a model based on firms' response to changes in the demand for their product in which change effects are structural and underly much of cyclical wage behavior, though there is also an effect from unemployment levels that grows as unemployment declines. See his "Inflation in Theory and Practice," BPEA, 1:1980, pp. 207-41.

36. Jeffrey Sachs and Charles Wyplosz, "The Economic Consequences of President Mitterand," Economic Policy, vol. 1 (April 1986), pp. 262-322; Schultze, "Real Wages"; $\rightarrow$ Robert J. Gordon, "Productivity, Wages, and Prices Inside and Outside of Manufacturing in the U. S., Japan, and Europe,' European Economic Review, vol. 31 (April 1987), pp. 685-733. 
To save space, wage and price equations are displayed only for the aggregate of 11 European countries and are contrasted with a simple price change equation for the interwar United States. The format of the wage and price change equations is identical. Changing productivity trends are taken into account by defining the wage change variable as the change in trend unit labor cost $\left(w-\theta^{*}\right)$. Changes in prices and labor cost are then explained by the same set of right-hand variables: two lags of price change, two lags of wage change, current and two lags of the output gap, the current change in relative :mport prices, and a dummy variable for "wage push" in $1968-70 .{ }^{37}$ Note that simultaneity bias is avoided by the exclusion of current labor cost in the price equation, and vice versa. The use of the output gap rather than the unemployment rate deals with the criticism of previous work by Blanchard and Summers that the unemployment rate in Europe is such a highly trended variable that its inclusion in wage equations does not give the level effect a chance and guarantees that the rate-of-change effect will prevail.

By a simple algebraic transformation, the lagged labor cost variable can be replaced by the change in labor's share $\left(w-\theta^{*}-p\right)$. In a simplified case with one lag and no other variables, one begins with:

$$
p_{t}=a p_{t-1}+b\left(w-\theta^{*}\right)_{t-1},
$$

and converts this to

$$
p_{t}=(a+b) p_{t-1}+b\left(w-\theta^{*}-p\right)_{t-1} .
$$

The transformation is intended to indicate whether changes in labor's share feed through to inflation or mainly induce an offsetting change in profits. A similar transformation converts the lagged price variable in the wage equation into the change in labor's share.

Because the main emphasis of my discussion of hysteresis is on separating level and rate-of-change effects, I experimented with alternative permutations of the current and two lagged output gap terms. By definition, these three terms can be written as three level terms, as two level terms and one change term, or as one level term and two change terms. I also allowed the coefficients on any of these terms to differ between the 1963-72 ("early") and 1973-86 ("late") intervals, while

37. Versions not reported here included in addition to or as alternatives to the import price either the relative price of oil in local currency or the change in the relative consumer price index. The relative import price performed better than these alternatives. 
imposing a single coefficient on all the other variables. The results were surprising and help account for differences here from equations I have run in previous papers with the same data. Inclusion of the second lagged term is crucial, because the rate-of-change effect in Europe operates with a one-year delay. ${ }^{38}$ Initial experimentation indicated that there is no significant difference in the coefficients on the lagged change in the output gap term in the early and late segments of the sample period, and they are combined here. The level effect benefits from the early-late split, particularly in the labor cost equation, which indicates a nearly significant and relatively large level effect before 1973 but not afterwards. In the price equation the level effect is insignificant throughout.

Of subsidiary interest are the terms on changes in labor's share of income. These suggest that wages matter for price behavior in Europe, but that prices do not matter for wages. These results are the reverse of those I recently obtained for the United States in quarterly data, and I must defer to subsequent research the question of the comparability of these results, ${ }^{39}$

To simplify the presentation in table 5, a U.S. interwar equation is shown only for price change, with no labor's share variable. The output gap variables are arranged differently, as the current level, and as the current and first lag on the difference, reflecting the pattern of the unrestricted coefficients estimated on the first round. The only other variable included besides two lags on the dependent variable is a dummy for the effects of the National Industrial Recovery Act, equal to +1 in 1933-34 and - 1 in 1935-36. The results are striking: the interwar United States is characterized by pure hysteresis, with a completely insignificant level effect. The main difference is that the inertia effect, measured by the sum of coefficients on past price changes, is unity in postwar Europe but only half that in the interwar United States.

AHEAD TO THE FUTURE AND BACK TO THE PAST: SIMULATION RESULTS

Table 6 uses the estimated equations in table 5 to simulate the effects of hypothetical future demand expansions in Europe in 1987-2006. Three

38. Blanchard and Summers ("Hysteresis") discovered the second-lag phenomenon in their first crack at the data, while it took me years to stumble onto this basic fact.

39. See Gordon, "The Role of Wages in the Inflation Process," American Economic Review, vol. 78 (May 1988, Papers and Proceedings, 1987), pp. 276-83. 
Table 5. Wage and Price Equations, Europe, 1963-86, and Price Equation, United States, 1922 -39 a

\begin{tabular}{|c|c|c|c|}
\hline \multirow[b]{2}{*}{ Independent variable } & \multicolumn{2}{|c|}{ Europe, 1963-86 } & \multirow{2}{*}{$\begin{array}{c}\text { United } \\
\text { States, } \\
\text { 1922-39 } \\
\text { Change in } \\
\text { GDP deflator } \\
\text { (3) }\end{array}$} \\
\hline & $\begin{array}{l}\text { Change in } \\
\text { GDP deflator } \\
\text { (1) }\end{array}$ & $\begin{array}{l}\text { Change in } \\
\text { trend unit } \\
\text { labor cost } \\
\text { (2) }\end{array}$ & \\
\hline Change in GDP deflator & $0.97^{\mathrm{b}}$ & & $0.39^{b}$ \\
\hline Change in trend unit labor cost & & $0.97^{\mathrm{b}}$ & $\ldots$ \\
\hline Change in labor's share & 0.62 & -0.03 & $\ldots$ \\
\hline \multicolumn{4}{|l|}{ Output ratio } \\
\hline Full period & & $\ldots$ & -0.02 \\
\hline Early period & -0.20 & 0.40 & $\ldots$ \\
\hline Late period & -0.14 & 0.07 & $\ldots$ \\
\hline \multicolumn{4}{|l|}{ Change in output ratio, full } \\
\hline $\begin{array}{l}\text { period } \\
\text { Change in relative import price }\end{array}$ & $\begin{array}{l}0.59^{\mathrm{b}} \\
0.04\end{array}$ & $\begin{array}{l}0.69^{\mathrm{c}} \\
0.05\end{array}$ & $0.63^{\mathrm{b}}$ \\
\hline $1968-70$ shock dummy variable & $1.13^{\mathrm{c}}$ & 1.58 & $\cdots$ \\
\hline $\begin{array}{l}\text { National Industrial Recovery Act } \\
\text { dummy variable }\end{array}$ & & $\cdots$ & $6.54^{\mathrm{b}}$ \\
\hline \multicolumn{4}{|l|}{ Summary statistic } \\
\hline $\bar{R}^{2}$ & 0.91 & 0.84 & 0.77 \\
\hline Standard error & 0.79 & 1.18 & 2.37 \\
\hline
\end{tabular}

Source: Author's calculations. See text description.

a. Dependent variable is the change in the GDP deflator (columns 1 and 3) and the change in trend unit labor cost (column 2). Figures shown are sums of coefficients on current and lagged variables where lag lengths were included as follows, with 0 indicating the current value, 1 the first lagged value, and 2 the second lagged value. Change in price deflator, lags 1-2; change in trend unit labor cost, lags 1-2; change in labor's share, lags 1-2; output ratio, all periods, lags $0-1$ for columns 1 and 2 , the current period only (lag 0) for column 3 ; change in output ratio, all periods, 1 lag for columns 1 and 2, lags $0-1$ for column 3; change in relative import price, current period (lag 0 ) only. The output ratio and change in output ratio variables were defined for the following intervals, and set to zero otherwise: full period, 1961-86; early period, 1961-73; late period, 1974-86. The 1968-70 shock dummy variable for the European equations is entered as 1.0 for the years 1968-70, and is zero otherwise. The National Industrial Recovery Act dummy variable is defined as 1.0 for $1933-34$, and -1.0 for $1935-36$.

b. Significant at the 1 percent level.

c. Significant at the 5 percent level.

simulations are provided. The price and labor-cost equations are solved simultaneously, thus generating the change in labor's share as an endogenous variable. The first column leaves Europe's 1986 output ratio of -3.4 percent intact over the full 1987-96 decade. The second column reduces this ratio steadily over the five years $1987-91$ and holds the ratio at zero thereafter. The third column expands output twice as fast, resulting in a positive ratio of 3.4 percent after 1991.

The simulations illustrate the theoretical result of equation 10 above. Inflation accelerates during the demand expansion but remains roughly constant thereafter, and there is no cost of going beyond the arbitrary 
Table 6. Simulation Results for Postwar Europe Price and Wage Equation, 1984-2006

Percent

\begin{tabular}{|c|c|c|c|}
\hline \multirow[b]{2}{*}{ Year } & \multicolumn{3}{|c|}{ Change in deflator } \\
\hline & $\begin{array}{l}\text { Trend output } \\
\text { growth }^{\mathrm{a}}\end{array}$ & $\begin{array}{c}\text { Faster } \\
\text { output growth }\end{array}$ & $\begin{array}{c}\text { Fastest output } \\
\text { growth }\end{array}$ \\
\hline & \multicolumn{3}{|c|}{ Actual values } \\
\hline 1984 & 5.04 & 5.04 & 5.04 \\
\hline 1985 & 4.61 & 4.61 & 4.61 \\
\hline 1986 & 4.17 & 4.17 & 4.17 \\
\hline \multicolumn{4}{|c|}{ Simulation results } \\
\hline 1987 & 3.84 & 3.84 & 3.84 \\
\hline 1988 & 3.78 & 4.16 & 4.54 \\
\hline 1989 & 3.54 & 4.46 & 5.33 \\
\hline 1990 & 3.45 & 4.85 & 6.28 \\
\hline 1991 & 3.32 & 5.28 & 7.25 \\
\hline 1992 & 3.25 & 5.79 & 8.31 \\
\hline 1993 & 3.18 & 5.92 & 8.65 \\
\hline 1994 & 3.14 & 5.94 & 8.73 \\
\hline 1995 & 3.10 & 5.96 & 8.83 \\
\hline 1996 & 3.07 & 5.97 & 8.86 \\
\hline 2006 & 2.97 & 6.00 & 9.03 \\
\hline
\end{tabular}

Source: Author's calculations based on regressions in table 5. Simultaneous solution of equations in columns 1 and 2 , reestimated with the insignificant output ratio term omitted.

a. The output ratio is assumed to be -3.4 for each year after the sample period.

b. Assumes the following time path of thie output ratio after the sample period: $1987,-2.7 ; 1988,-2.0 ; 1989$, $-1.4 ; 1990,-0.7 ; 1991-2006,0.0$.

c. Assumes the following time path of the output ratio after the sample period: $1987,-2.0 ; 1988,-0.7 ; 1989,0.7$; $1990,2.0 ; 1991-2006,3.4$.

barrier of a zero output ratio, because the NAIRU will tag along in response to any degree of demand expansion. The resulting inflation, which allows labor's share to adjust endogenously, is faster than an alternative simulation that unrealistically holds labor's share constant, because the change in the output ratio raises both the inflation rate and labor's share. As indicated in the second column, a permanent 3.4 percent increase in output each year can be purchased at the cost of a permanent 3.0 percentage point increase in the inflation rate. The third column indicates that a permanent 6.8 percent increase in output raises inflation by 6.0 percentage points permanently. While this trade-off may appear to be unfavorable, the important point is that the output benefit is permanent. Thus, at the cost of 3 percent inflation, Europe could enjoy 34 percent more output over the next decade and 68 percent more over the next two decades. 


\section{Conclusion}

Of the similarities between the situation of high-unemployment 1939 America and high-unemployment contemporary Europe, the most important is hysteresis in the inflation rate: the output gap affects inflation only through its rate of change, not its level, and there is no downward pressure on the inflation rate from the level of the output gap, no matter how large. Hysteresis reconstructs the permanent output-inflation tradeoff that was cast into the wilderness 20 years ago by Friedman's natural rate hypothesis; Europe can choose to achieve a permanent increase in output at the cost of a permanently higher but not accelerating inflation rate.

Two conditions, however, are necessary for a permanent trade-off. Not only must output (or unemployment) operate purely through its change rather than its level, but also the inertia effect of lagged inflation in the inflation equation must operate with a coefficient of unity. This most emphatically did not occur in interwar America, and as a result 1939 America did not face Europe's difficult choice today. A permanent increase in output in 1939, even without wartime price controls, would have created only a temporary inflation bulge.

Two other differences between 1939 America and contemporary Europe are that the United States had more of a problem of excess real wages in 1939 than appears to be the case in Europe today and that the United States had, by available measures, a much more serious capital stock bottleneck. Yet the lesson of 1939-41, and indeed of 1939-48, is that the capital stock can be extremely elastic when labor is available to be hired by firms. Europe has experienced a continuing increase in the capital stock relative to output, but because the real wage bulge of the 1970s has now been eliminated, it is hard to argue that rapid capital stock growth in Europe is entirely due to substitution away from labor toward capital. The 1939 precedent and the sheer magnitude of growth in Europe's capital stock in the last decade and a half argue that the capital is there if the demand for output can be created.

The paper reviews a number of structuralist explanations of the upward-creeping European NAIRU and finds no factor or combination of factors that seems quantitatively up to the task. The discussion of hysteresis and the NAIRU attempts to reorient the explanation toward 
a longer historical perspective. The level effect of high unemployment or a large output gap has always disappeared in prolonged recessions, suggesting that the fundamental mechanism by which demand influences inflation is its rate of change rather than its level. The analysis leaves as an open question whether the demand influence works differently in booms than in recessions; prolonged booms not associated with wartime distortions are sufficiently rare that this asymmetry may be difficult to test. 


\section{Comments \\ and Discussion}

Charles L. Schultze: In one fell swoop, Robert Gordon's paper

- discards, as far as Europe is concerned, the standard augmented Phillips curve in the shape it is usually given, of which Gordon was a principal architect and practitioner;

- disavows the NAIRU as a concept with which to explain European wage and price inflation, arguing that any old unemployment rate will be consistent with stability of the inflation rate;

-tells us that, in Europe at least, a wage-wage rather than a wageprice process is at work.

The first two of these new findings arose because Gordon stumbled into shifting the rate-of-change variable in his wage and price equations from a contemporaneous to a one-period lag. It's a little bit as if the pope had issued a new bull renouncing the concept of the virgin birth because he discovered a faulty translation of a single phrase in the gospel of St. John. The recent path of European inflation, unemployment, and output, particularly the failure of wage and price inflation to continue falling in the face of high unemployment, coupled with the inability of a host of researchers to find any dominant structural culprit, does indeed warrant some heresy. What Gordon has done is not so much to change his earlier view-namely, that Europe has room for a permanent output expansion-as to get to that conclusion with a new doctrine. I am sympathetic to much of what Gordon has to say, but I have two criticisms. First, he has not convincingly made the case that wage inflation is affected only by the change in excess demand and not by its level. Second, while I agree that an important part of the 15-year rise in European unemployment cannot be explained by structural elements, Gordon goes too far in playing down the role of such elements in explaining the increase.

Gordon interprets his new finding-that it is the rate of change in 
excess demand rather than its level that influences the inflation rate-to imply that workers fear for their jobs and moderate wage demands only when unemployment is rising and layoffs are high. They lose that fear when unemployment settles down to a higher but stable level. If the coefficient on past wage or price inflation is close to unity, this behavior returns us to the good old-fashioned stable Phillips curve. The implication for Europe is that it can "buy" a permanent reduction in unemployment for a permanently higher inflation rate. Gordon leaves open, but remains agnostic about, the possibility that the influence of the level of excess demand may reassert itself in periods of high employment so that an accelerationist process can take over, as it evidently did in the United States from 1965 to 1969.

I find much to commend in a model in which the rate of flow into and out of unemployment influences inflation when unemployment is high, while the level of unemployment asserts itself when unemployment is low. George Perry presented such a model in a 1980 paper in this journal. ${ }^{1}$ But I do not think that Gordon makes a convincing case for that result in this paper. First, Gordon arrives at his result when he shifts the rateof-change variable in his wage and price equations from a contemporaneous to a lagged variable. I cannot believe that one can really choose among such fundamentally different interpretations of economic behavior on the basis of coefficients and $t$-statistics separated by a one-period lag in a time series analysis with not much more than 15 degrees of freedom.

Second, there is even more reason to be dubious. The dominance of the rate-of-change effect in these latest wage equations is not independent of Gordon's substitution of a lagged wage variable for the lagged price variable on the right-hand side of the equation. Using my own data on the nonfarm business economy, rather than the total economy, but with the same output ratio and the same trend productivity change as Gordon uses, I fit wage equations for Germany and France that are quite similar in structure to his own. In both countries when lagged price inflation is used on the right-hand side of the equation, it is the level of the output ratio that carries a significant $t$-statistic-the coefficient on the change in the output ratio is much smaller and insignificant. But when lagged wage inflation is used on the right-hand side, then the change in the output ratio does become significant; in Germany the level of the output

1. George L. Perry, "Inflation in Theory and Practice," BPEA, 1:1980, pp. 207-41. 
ratio becomes insignificant, while in France the level variable retains significance. Thus, it is Gordon's use, in his latest wage equations, of lagged wage inflation, rather than lagged price inflation, on the righthand side that produces the dominance of a rate-of-change effect over a level effect. Gordon notes that when he enters both wage and price inflation on the right-hand side, the former drives out the latter. His equation is for Europe as a whole; in my experiments the specification with lagged wages gives a better fit for Germany, while in France the opposite is true.

I have not been able to figure out why this result occurs. But the message is that changes in specifications with respect to one variable in aggregate wage or price equation can radically alter the results for other variables, and without strong priors it is hazardous to draw conclusions about which particular form of the excess demand variable is the proper one. This warning is especially important when alternative forms of that variable have vastly different implications both for explaining history and for drawing policy conclusions.

Finally, when one uses the output ratio as the excess demand variable, as Gordon and I do in lieu of an unemployment measure, there is a potential error-in-variables problem. Year-to-year changes in the output ratio are not sensitive to the accuracy of potential GNP. But comparing the output ratio of one period with that of another separated by many years is subject to more substantial measurement error, especially when the critical past five or six years in Europe have no period of high employment against which to benchmark the potential GNP measure. And the measurement errors tend to bias down the coefficient on the level variable relative to the coefficient of the rate-of-change variable.

There is one ironic sidelight to Gordon's new results, compared with several of his recent papers on European unemployment. At first sight it would seem that the new results are more optimistic, because according to the new version Europe does have trade-off possibilities and is not confronted by a stubborn NAIRU that defies a trade-off. But the earlier papers, which did incorporate a NAIRU concept, concluded that Europe's NAIRU was well below its actual unemployment rate, so that aggregate demand policy could lower unemployment without any inflation cost. Now he tells us that there is a trade-off and it would cost Europe a significant and "permanent" rise in inflation to get unemployment substantially down from its current 10 percent level.

There are some other dynamic consequences of accepting Gordon's 
new formulation. If wage inflation is influenced by lagged wage inflation, and not by lagged or expected price inflation, then a continuing supply shock, such as a permanent drop in the trend rate of productivity growth, will have only a one-time effect on the inflation rate. If the monetary authorities are willing to accept that one-time rise, the supply shock would have no effect on employment. But if, as Gordon used to believe, wage inflation runs off lagged price inflation, with a coefficient close to unity, supply shocks will lead to potentially accelerating inflation that can be stopped only if the monetary authorities create a permanent rise in unemployment.

I agree with Gordon that in Europe, and especially in Germany, the structural explanation for the increase in Europe's unemployment has been vastly exaggerated. But he assigns it too small a role. Since the early 1970 s the unemployment rate in the four large European economies has risen from 2.5 percent to 10 percent. By no means all, but a significant part, of that rise is structural. I doubt if anyone really thinks that demand management policy could push the unemployment rate back down anywhere near 2.5 percent without giving rise to an acceleration of inflation.

To be more specific about the nature of the problem, I have to digress for a moment to explain my view of the relationship among real wages, inflation, and unemployment. I take off from one of Gordon's earlier formulations, which unfortunately he abandoned in this paper.

What is critical in determining the long-run sustainable level of unemployment is not real wages, but the relationship between, on the one hand, the schedule of aspirations for real wage growth and, on the other, the supply conditions of the economy, as given principally by the growth of productivity, the terms of trade, and the balance between the mix of characteristics of the unemployed and job vacancies. (The schedule of real wage aspirations relates nominal wage settlements to the unemployment rate and the rate of inflation.) If workers and employers agree on nominal wage increases, relative to the ongoing rate of inflation, that are too high to be consistent with the maintenance of that ongoing rate of inflation, given the rate of growth in productivity and changes in the terms of trade, inflation will increase. (A fall in the rate of productivity growth not accompanied by a corresponding fall in wage aspirations would be an example of this situation.) If wage bargains persist in this effort, inflation will accelerate. Ultimately, but usually 
after some time lag and some rise in inflation, the monetary authorities will call a halt by restricting aggregate demand and raising unemployment to the point where wage settlements moderate enough to stop the rise in inflation. Unless the schedule of wage aspirations shifts down, unemployment will rise and stay high.

Whether, in this process, actual real wages rise depends on employers' pricing practices-whether the fall in aggregate demand and employment squeezes the margin of prices over average unit labor costs. The sustainable rate of unemployment does not depend on real wage outcomes, which are endogenous, but on the ultimate need to eliminate the inflationary consequences of real wage aspirations that are inconsistent with the growth of productivity and other supply conditions.

In the 20 years before 1973, conditions in Europe were peculiarly suitable for achieving and maintaining low unemployment. The puzzle of European unemployment is as much why it was so low in the 1960s as why it is so high now. According to Angus Maddison, productivity growth in Europe during the 1950s and 1960s was three times what Europe had experienced in the prewar 80 years. ${ }^{2}$ As a consequence, with attitudes conditioned by past history, the schedule of wage aspirations was low enough relative to the unprecedented productivity growth that it was possible to move up that schedule to a very high level of employment without generating a rising inflation rate. Because Europe was in a catch-up position with respect to the technological frontier, profit rates were also exceedingly high, although falling, during the period.

By the late 1960s, as employees became aware of the high profits, they raised their schedule of wage aspirations, which in turn increased the level of unemployment consistent with a stable inflation rate. In the early 1970s the rate of productivity growth fell off sharply; averaged over the four large European countries, that decline, in my estimates, amounted to almost 2.5 percent a year, which in turn further raised the level of unemployment necessary to keep the inflation rate from rising.

The estimates in my paper on real wages in the Brookings Barriers to European Growth volume suggest there has recently been some downward adjustment of the schedule of real wage aspirations, offsetting part

2. Angus Maddison, "Growth and Slowdown in Advanced Capitalist Economies: Techniques of Quantitative Assessment," Journal of Economic Literature, vol. 25 (June 1987), pp. 649-98. 
of the effects of the lower productivity growth. ${ }^{3}$ But, net, the unemployment rates consistent with stable inflation have increased in Europe.

Finally, I think, for three reasons, that Gordon has too casually dismissed the significance of the upward shift in the Beveridge curve and the decline in the apparent mobility of the labor force in Europe.

First, in the United Kingdom the eye itself can pick out the large and obvious upward shift in the unemployment-vacancy relationship that is not, as Gordon suggests, a phenomenon associated with having reached a "minimum" number of vacancies.

Second, although the case in Germany is a little more difficult, a recent paper by Wolfgang Franz first corrects the German unemployment rate to include discouraged workers and people on training programs and then finds an upward shift in the $U V$ curve that is quite substantial and can be extracted with the use of dummies in a nonlinear $U V$ curve. ${ }^{4}$ The shift occurs at vacancy rates well above the bare minimum.

Third, admittedly, nobody has successfully identified the causes of the decrease in the unemployment-adjusted mobility of the European work force. Most of the efforts to trace it to a growing industrial or regional mismatch have failed. But it did occur, and it did raise the structural level of unemployment.

In sum, I think Gordon has made a good case against many of the arguments that deny Europe's ability to reduce unemployment by expanding aggregate demand. I am sympathetic to, but do not think he has really made the case for, a stable Phillips curve, at least at moderate to high levels of employment. And, finally, while I agree that an important part of Europe's increase in unemployment is not structural, an important part is.

\section{General Discussion}

Some panelists felt that Gordon was too quick to dismiss all structural explanations of high unemployment in Europe. Olivier Blanchard ex-

3. Charles L. Schultze, "Real Wages, Real Wage Aspirations, and Unemployment in Europe," in Robert Z. Lawrence and Charles L. Schultze, eds., Barriers to European Growth: A Transatlantic View (Brookings, 1987), pp. 230-91.

4. Wolfgang Franz, "Hysteresis, Persistence, and the NAIRU: An Empirical Analysis for the Federal Republic of Germany," in Richard Layard and Lars Calmfors, eds., The Fight Against Unemployment: Macroeconomic Papers from the Centre for European Policy Studies (MIT Press, 1987), pp. 91-122. 
pressed some sympathy for an alternative explanation, based on structural factors. Under that explanation, Europe has witnessed a steady shift in the composition of demand for labor from unskilled to skilled workers. Why this shift has taken place is not entirely clear but may have to do with an increased need for "flexible specialization" in production. The presence of high floors on the wage that can be paid to workers with low skills may then account for a high rate of unemployment among unskilled workers in Europe. However, Martin Baily pointed out that a concentration of unemployment among unskilled workers is also a common symptom of deficient aggregate demand. He argued that the distribution of unemployment in Europe is thus not persuasive evidence that structural factors are the source of high European unemployment rates. Edmund Phelps offered an alternative structural explanation for high unemployment in Europe based on the theory that price markups are positively related to the real interest rate. The dramatic rise in real interest rates in the 1980s should both raise price markups and reduce employment, either because the monetary authority is unprepared to accommodate the higher price level or because workers are unwilling to accept a lower real wage. But Alan Blinder observed that Phelps's explanation could not account for the different employment patterns in Europe and the United States.

George von Furstenberg criticized the use of closed-economy models for analyzing the effect of increases in aggregate demand on European unemployment. He said that using aggregate demand policy to deal with structural unemployment in Germany is about as appropriate as using it to deal with structural unemployment in Texas. He reasoned that German firms are actually relocating in other parts of the world because the dollar wages of German production workers are, by his estimates, 43 percent higher than the wages of their U.S. counterparts. Expanding aggregate demand would not solve that problem.

A number of panelists questioned Gordon's shift of emphasis from the level of unemployment to the change in unemployment as the labor market variable in Phillips curves. Even if Gordon's parsimonious specification gives most of the credit to the rate of change, it does not have much power to distinguish level and rate-of-change effects. Blinder asserted that the level of unemployment has for most periods been the more important effect in the Phillips curve. Phelps reasoned that although there might be an interval over which the level of unemployment has little effect on inflation, the level effect may reexert itself when the 
unemployment rate falls low enough. James Tobin cautioned that the lack of disinflation in Europe despite high unemployment may be misinterpreted as an outward shift of the Phillips curve. Alternatively, it may be evidence of a Phillips curve with a large flat region, along the lines suggested by Phelps. On this interpretation, an increase in aggregate demand in Europe could reduce unemployment without generating inflation.

Absence of an effect of unemployment levels on inflation is closely related to the idea of hysteresis. William Brainard related some evidence, provided by Lawrence Summers, in favor of the hysteresis explanation of unemployment in Great Britain. Union leaders were found to have no idea how many of their members were unemployed. Furthermore, employed workers did not report increased worry about losing jobs as the unemployment rate rose in England. And current hiring rates are high and separations low, a pattern that looks more like a cyclical peak than a situation of near-record unemployment. Blinder argued that although hysteresis models may explain why market pressures to restore full employment are weak, the models are not necessarily pessimistic about the ability of greater demand to reduce unemployment because hysteresis is reversible. Human capital skills can be rebuilt by putting the unemployed to work. A burst of aggregate demand will generate physical capital formation and reemploy nonunion outsiders. However, Baily felt that Blinder was overly sanguine about the speed with which hysteresis could be reversed, arguing that capital stock that deteriorated over a long period of high unemployment might take a comparable time to replace. 